\title{
The quantification of testicular cells during the postnatal development in two Caviomorph rodents: the guinea pig (Cavia porcellus) and the cutia (Dasyprocta agouti)
}

\author{
LUCIANA S. SIMÕES ${ }^{1}$, TAIS H.C. SASAHARA ${ }^{2}$, PHELIPE O. FAVARON ${ }^{1}$, RICARDO MARQUES \\ JÚNIOR ${ }^{1}$, MOACIR F. DE OLIVEIRA ${ }^{3}$, MÁRCIA R.F. MACHADO ${ }^{4}$ and MARIA ANGELICA MIGLINO ${ }^{1}$ \\ ${ }^{1}$ Departmento de Cirurgia, Faculdade de Medicina Veterinária e Zootecnia, Universidade de São Paulo/FMVZ- \\ USP, Av. Prof. Dr. Orlando Marques de Paiva, 87, Cidade Universitária, 05508-270 São Paulo, SP, Brazil \\ ${ }^{2}$ Hospital Veterinário, Universidade de Franca/UNIFRAN, Av. Dr. Armando Salles \\ Oliveira, 201, Pq. Universitário, 14404-600 Franca, SP, Brazil \\ ${ }^{3}$ Universidade Federal Rural do Semi-Árido, Departmento de Ciências Animais, BR \\ 110, Km 47, s/n, Costa e Silva, 59625-900 Mossoró, RN, Brazil \\ ${ }^{4}$ Departamento de Morfologia e Fisiologia Animal, Universidade Estadual Paulista/UNESP, Faculdade de Ciências \\ Agrárias e Veterinárias/FCAV, Via de Acesso Prof. Paulo Donato Castellane, s/n, 14884-900 Jaboticabal, SP, Brazil
}

Manuscript received on January 19, 2017; accepted for publication on March 6, 2017

\begin{abstract}
The germinative, Sertoli and Leydig cells of two caviomorph rodents (Cavia porcellus and Dasyprocta agouti) were counted as well as the estimation of the total volume of the testis and the total volume of seminiferous tubules and interstitium in prepubertal, pubertal and adult animals. The number of spermatogonia, spermatocytes and spermatids cells increased during the pubertal phase in both rodents, notably the spermatid cells. The spermatocyte and spermatid slightly decreased in the adult of both rodents, but the increment in spermatogonia cells number was seen, mainly in cutias. The number of Sertoli cells increased in pubertal rodents, but in the adult the number reduced. Substantial number of Leydig cells was counted in pubertal and adult guinea pigs. In cutias, the number of Leydig cells increased in pubertal phase and decline in adults. The design-based stereological method has proven to be unbiased and reliable to be applied in reproduction studies.
\end{abstract}

Key words: Germinative cells, hystricomorpha, reproduction, stereology.

\section{INTRODUCTION}

The guinea pig (Cavia porcellus) and the cutia (Dasyprocta agouti) are rodents that belong to the Hystricomorpha suborder and Caviomorpha infraorder. The geographical habitat of the guinea pig ranges from Colombia and Venezuela to

Correspondence to: Maria Angelica Miglino

E-mail:miglino@usp.br northern Argentina and that of the cutia ranges from Colombia to southern Brazil (Mackenzie 1972).

The guinea pigs are medium-sized rodent extensively used to support biomedical researches due to their similarities to the human immune system response (Padilla-Carlin et al. 2008, Welkos et al. 2015). The cutia has great importance to animal production as an alternative source of protein; it has been used as an experimental animal 
in reproduction studies with important application in wild animal conservation (Arroyo et al. 2014, Castelo et al. 2015).

The knowledge of the reproduction function is vital to establish the appropriate animal management to guarantee reproduction successful (França and Russell 1998).

The study of the testicular parenchyma is a useful tool to evaluate the spermatogenic capacity in normal, pathologic and experimental conditions (Cardoso 2009). Several studies have quantified the testicular cells using different techniques, as proposed by Bellvé et al. (1977), but most of then use histomorphometry (Nunes et al. 2013, De Melo et al. 2013, Morais et al. 2014). Thus, this work aims to estimate the number of testicular cells in two Caviomorph rodents during the postnatal development, applying design-based stereological techniques as an accurate tool.

\section{MATERIALS AND METHODS}

\section{ANIMALS}

This study used testes from nine guinea pigs (30, 45 and 90 days old), (body weights ranging from $248 \mathrm{~g}$ to $582 \mathrm{~g})(\mathrm{n}=3)$ and from nine cutias (5-8 months, 9-11 months and 12 months old), (body weights ranging from $1634 \mathrm{~g}$ to $2735 \mathrm{~g})(\mathrm{n}=3)$. For the bilateral orchiectomy, the anesthetic protocol was: ketamine $75-100 \mathrm{mg} / \mathrm{kg}$ intraperitoneal (IP) and xylazine $10 \mathrm{mg} / \mathrm{kg}$ IP. The experimental procedures were approved by the Ethical Committee of the Animal Experimentation of the College of Veterinary Medicine - University of São Paulo (FMVZ-USP) (protocol number 8735070714).

\section{QUANTITATIVE STUDY}

\section{Te total volume of the testes V(ref)}

The total volume of the testis was estimated dividing the fresh organ weight, in grams, by the mean density of the testicular tissue: $1.04 \mathrm{~g} / \mathrm{cm}^{3}$ (Mori and Christensen 1980).

Sampling of the testes

The right or left testis of guinea pig and cutia was randomly chosen and they were fixed by immersion in paraformaldehyde $4 \%$ for $24 \mathrm{~h}$ at $4{ }^{\circ} \mathrm{C}$. Following the fixation, the chosen testis was cut in slices (3-mm-thick slices) (resulting in a total of 6-8 slices). Every second slice was chosen. The chosen slices were cut in bars (resulting in a total of 12-16 bars). Every second bar was chosen. And finally, the chosen bars were cut in blocks of different size (resulting in a total of 6-8 blocks) and these blocks were organised in a crescentsize arrangement, according to the principle of the Smooth Fractionator (Gundersen 2002). Every third or fourth block was chosen. The slices, bars, and fragments were sampled by the systematic, uniform and randomly (SUR) principle (Gundersen et al. 1999).

Total number of sertoli cells, spermatogonia, spermatocyte, spermatid and leydig cells

The sampled blocks were embedded in Araldite 502 (Electron Microscopy Sciences) and sections of $0.5 \mu \mathrm{m}$ were exhausted cut in ultramicrotome (LEICA ULTRACUT UCT ${ }^{\circledR}$ ). The sections were collected on slides and stained with Toluidine Blue. Every second or third section was chosen and the cell counting was performed in 1/250 of the sampled tissue section. The principle of the physical fractionator (Gundersen 1986) was used to estimate the total number of Sertoli cells, Leydig cells, spermatogonia, spermatocyte and spermatid cells. This principle is based on randomly sampling a preview known fraction of a structure and then counting the particles in this fraction. This method consists in multiplying the number of particles (Q) by the inverse of the sampled fractions: sfs (slices), sfb (bars), sfb (blocks), sfsc (sections) and 
sfa (area). Two parallel physical sections, with a known distance, were used. The first section is the reference section and the second one, the look-up section. The distance between the "reference" and "look-up" sections was $4 \mu \mathrm{m}$. The counting frame, with the total area $\left(1.8 \times 10^{6} \mu \mathrm{m}^{2}\right)$ was used to unbiased counting the particles.

Volume density of seminiferous tubules $V v(t)$ and volume density of interstitium $V v(i)$

The fractional volume of seminiferous tubules and interstitium was determined by point counting. Sections were sampled following SUR principle. On each sampled section a point system (distance between points was $125 \mu \mathrm{m}$ ) were used. The total of points hitting the testis reference space ( $\Sigma$ Pref) were counted, as well as the points hitting the seminiferous tubules $(\Sigma \mathrm{Pt})$ and the interstitium $(\Sigma \mathrm{Pi})$. The $\mathrm{Vv}_{\mathrm{v}}(\mathrm{t})$ was estimated as: $\mathrm{Vv}_{\mathrm{v}}(\mathrm{t})=(\Sigma \mathrm{Pt}) /$ $(\Sigma$ Pref $)$ and $\mathrm{Vv}_{\mathrm{v}}(\mathrm{i})$ was estimated as: $\mathrm{Vv}(\mathrm{i})=(\Sigma \mathrm{Pi}) /$

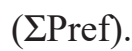

Total volume of seminiferous tubules (Vt) and total volume of interstitium (Vi)

The total volume of the seminiferous tubules (Vt) was calculated multiplying the $V_{v}(t)$ by the total volume of the testes $\mathrm{V}(\mathrm{ref})$ and the total volume of interstitium (Vi) was calculated multiplying the $\mathrm{VV}$ (i) by the total volume of the testes V(ref).

\section{STATISTICAL ANALYSIS}

The data were analyzed by one-way ANOVA. The quantitative results were shown as mean followed by the coefficient of variation (CV). The difference between groups was considered significant when the p-value was less then 0.05 . Tukey test was applied when differences were considered significant. The Minitab Express statistical software was used for the analysis.

\section{RESULTS}

TOTAL VOLUME OF TESTIS, SEMINIFEROUS TUBULES AND INTERSTITIUM

The mean values of the total volume of the testis (Vref) as well the fractional volume occupied by seminiferous tubules (Vt) and interstitium (Vi) were statistically different comparing the guinea pig groups. The Vref ranged from 0.16 to 0.55 $\mathrm{cm}^{3}(\mathrm{p}<0.01)$, the $\mathrm{Vt}$ ranged from 0.13 to $0.50 \mathrm{~cm}^{3}$ $(p<0.05)$ and Vi ranged from 0.03 to $0.06 \mathrm{~cm}^{3}$ $(p<0.05)$. The percentual values of the fractional volume occupied by $\mathrm{Vt}$ ranged from $81 \%$ to $89 \%$ and the fractional volume occupied by Vi ranged from $19 \%$ to $11 \%$, comparing prepubertal to adult guinea pig. In cutias, no difference between groups was detected for Vi. The Vref ranged from 1.65 to $3.64 \mathrm{~cm}^{3}(\mathrm{p}<0.05)$, the $\mathrm{Vt}$ ranged from 1.15 to $3.22 \mathrm{~cm}^{3}(p<0.01)$ and Vi ranged from 0.50 to $0.41 \mathrm{~cm}^{3}$. The percentual values of the fractional volume occupied by $\mathrm{Vt}$ ranged from $70 \%$ to $89 \%$ and the percentual values of the fractional volume occupied by Vi ranged from $30 \%$ to $11 \%$. The age groups mean values are shown in Tables I and II.

\section{TOTAL NUMBER OF GERMINATIVE, SERTOLI AND} LEYDIG CELLS

The guinea pig germinative, Sertoli and Leydig cell numbers were different between groups. The Sertoli cells ranged from 2.82 to $3.21 \times 10^{6}$ $(\mathrm{p}<0.01)$, spermatogonia ranged from 0.67 to 1.14 $\mathrm{x} 10^{6}(\mathrm{p}<0.05)$, spermatocyte ranged from 3.54 to $4.41 \times 10^{6}(\mathrm{p}<0.01)$, spermatid ranged from 0.95 to $3.21 \times 10^{6}(\mathrm{p}<0.001)$ and Leydig cells ranged from 0.15 to $0.63 \times 10^{6}(\mathrm{p}<0.01)$. The cutia germinative cells were different between groups, however, no difference was observed in Sertoli and Leydig cells. Sertoli cells ranged from 19.80 to $20.06 \times 10^{6}$, spermatogonia ranged from 4.00 to $4.86 \times 10^{6}(\mathrm{p}<$ $0.05)$, spermatocyte ranged from 9.50 to $12.12 \times 10^{6}$ $(p<0.01)$, spermatid ranged from 3.40 to $11.42 \times 10^{6}$ $(p<0.001)$ and Leydig cells ranged from 5.02 to 
TABLE I

The mean values of the total volume of the testis (Vref), seminiferous tubules $(\mathrm{Vt})$ and interstitium (Vi) in guinea pig.

\begin{tabular}{cccc}
\hline Volume $\left(\mathbf{c m}^{3}\right)$ & PP & P & $\mathbf{A}$ \\
\hline $\begin{array}{c}\text { Volume of testis } \\
\text { (Vref)** }\end{array}$ & $0.16(0.15)$ & $0.27(0.11)$ & $0.55(0.35)$ \\
$\begin{array}{c}\text { Volume of } \\
\text { tubules (Vt)* } \\
\quad \text { Volume of } \\
\text { interstitium (Vi)* }\end{array}$ & $0.13(0.20)$ & $0.23(0.11)$ & $0.50(0.37)$ \\
& & & \\
\end{tabular}

Group differences: ${ }^{*} \mathrm{p}<0.05 ; * * \mathrm{p}<0.01$.

$5.76 \times 10^{6}$. The age groups mean values are shown in Tables III and IV and the seminiferous tubule cells (Figure 1).

\section{DISCUSSION}

Our results showed that the increment in total volume of testes is closely related to the increase in the size of seminiferous tubules in cutia and in guinea pig. When comparing prepubertal to adult testes, the fractional volume occupied by the seminiferous tubules increased from $81 \%$ to $89 \%$ in guinea pig and from $70 \%$ to $89 \%$ in cutia.

According to Short (1997), the only way to increase the sperm production is by increasing the volume of seminiferous tubular tissue and testicular size, because the rate of sperm production per gram of testicular tissue is almost constant within the species. Zhengwel et al. (1997) showed that the number of germinative cells is strongly related to testicular volume.

Considering the number of germinative cells in guinea pig and cutia, the most numerous type of cells was spermatocyte, followed by spermatid and spermatogonia. The number of spermatocytes increased 33\% in pubertal guinea pigs and 29\% in cutias. Bellvé et al. (1977) obtained cells from the seminiferous epithelium by sedimentation and they were able to identify spermatocytes in different phases $31 \%, 21 \%$ and $89 \%$ were respectively in leptotene, zygotene, and pachytene. Rodríguez
TABLE II

The mean values of the total volume of the testis (Vref), seminiferous tubules (Vt) and interstitium (Vi) in cutia.

\begin{tabular}{cccc}
\hline Volume $\left(\mathbf{c m}^{3}\right)$ & PP & P & A \\
\hline $\begin{array}{c}\text { Volume of testis } \\
(\text { Vref)* }\end{array}$ & $1.65(0.50)$ & $2.68(0.14)$ & $3.64(0.05)$ \\
$\begin{array}{c}\text { Volume of tubules } \\
(\text { Vt) }\end{array}$ & $1.15(0.46)$ & $2.15(0.15)$ & $3.22(0.07)$ \\
$\begin{array}{c}\text { Volume of } \\
\text { interstitium (Vi) }\end{array}$ & $0.50(0.60)$ & $0.52(0.13)$ & $0.41(0.10)$
\end{tabular}

Group differences: ${ }^{*} \mathrm{p}<0.05 ; * * \mathrm{p}<0.01$.



Figure 1 - Pre-pubertal cutia, spermatocytes (arrowhead), Sertoli cells (filled arrows) (a); Pubertal cutia, spermatocytes (arrowhead), Sertoli cells (arrows), spermatids (dashed arrows) (b). Adult cutia, spermatid (dashed arrows), lumen of seminiferous tubule with spermatozoa (S) (c) Pre-pubertal guinea pig, sertoli cells (arrows), spermatocytes (arrowhead) and spermatids (dashed arrow) (d). Pubertal guinea pig, germinative epithelium (Ep.G) with spermatids (dashed arrows) (e). Adult guinea pig, germinative epithelium (Ep.G) with spermatozoa (S) (f). Toluidine blue. 
TABLE III

The mean values of the total number of Sertoli cells, spermatogonia, spermatocyte, spermatid and Leydig cells in guinea pig.

\begin{tabular}{|c|c|c|c|}
\hline $\begin{array}{c}\text { Number of cells } \\
\qquad\left(10^{6}\right)\end{array}$ & $\mathbf{P P}$ & $\mathbf{P}$ & $\mathbf{A}$ \\
\hline Sertoli cells** & $2.82(0.06)$ & $\begin{array}{c}3.60 \\
(0.05)\end{array}$ & $3.21(0.09)$ \\
\hline Spermatogonias* & $0.67(0.16)$ & $\begin{array}{c}0.87 \\
(0.17)\end{array}$ & $1.14(0.09)$ \\
\hline Spermatocytes** & $3.54(0.04)$ & $\begin{array}{c}4.71 \\
(0.06)\end{array}$ & $4.41(0.04)$ \\
\hline Spermatids*** & $0.95(0.12)$ & $\begin{array}{c}3.37 \\
(0.10)\end{array}$ & $3.21(0.09)$ \\
\hline Leydig cells** & $0.15(0.10)$ & $\begin{array}{c}0.38 \\
(0.19)\end{array}$ & $0.63(0.23)$ \\
\hline
\end{tabular}

Group differences: ${ }^{*} \mathrm{p}<0.05 ; * * \mathrm{p}<0.01 ; * * * \mathrm{p}<0.001$.

and Wettstein (2004) applying similar quantitative analysis reported $5.5 \%$ leptotene/zygotene spermatocyte of total cells in the guinea pig.

A peak of spermatid proliferation was observed in pubertal guinea pig and cutia. The number of these cells increased around $250 \%$ in both species and is coincident with the beginning of the production of spermatozoa. Slightly reduction of $5 \%$ in spermatid number was observed in adult animals from both species. This reduction might be related to the reduction of sperm production with age. In men, Jonhson et al. (1987) reported the reduction of early spermatid when evaluating the potential daily sperm production per gram of parenchyma.

In guinea pig, comparing prepubertal and pubertal animals, the number of spermatogonia increased approximately $30 \%$, the same increase was observed when the pubertal animals were compared to the adult group. In cutias, however, the number of spermatogonia from prepubertal to pubertal ages increased only $2.5 \%$ and the increment of $18.5 \%$ was observed comparing the pubertal to adult animals. According to Okwun et
TABLE IV

The mean values of the total number of Sertoli cells, spermatogonia, spermatocyte, spermatid and Leydig cells in cutia.

\begin{tabular}{|c|c|c|c|}
\hline $\begin{array}{c}\text { Number of cells } \\
\qquad\left(10^{6}\right)\end{array}$ & $\mathbf{P P}$ & $\mathbf{P}$ & $\mathbf{A}$ \\
\hline Sertoli cells & $19.80(0.03)$ & $\begin{array}{l}20.90 \\
(0.02)\end{array}$ & $20.06(0.07)$ \\
\hline Spermatogonias* & $4.00(0.07)$ & $\begin{array}{c}4.10 \\
(0.09)\end{array}$ & $4.86(0.06)$ \\
\hline Spermatocytes** & $9.50(0.12)$ & $\begin{array}{l}12.25 \\
(0.04)\end{array}$ & $12.12(0.03)$ \\
\hline Spermatids $* * *$ & $3.40(0.12)$ & $\begin{array}{l}12.00 \\
(0.10)\end{array}$ & $11.42(0.09)$ \\
\hline Leydig cells & $5.02(0.07)$ & $\begin{array}{c}5.98 \\
(0.20)\end{array}$ & $5.76(0.20)$ \\
\hline
\end{tabular}

al. (1996), the ration based on the most and the least advanced germ cell represents rates of cellular yield or degeneration, indicating the efficiency of spermatogenesis. Applying this concept to our results, the lowest ration between the spermatid/ spermatogonia was observed in adult guinea pig and cutia showed poor cellular degeneration during spermatogenesis.

In our study, the Sertoli cells number increased $27 \%$ comparing prepubertal and pubertal testes, but decreased $12 \%$ comparing pubertal to adult one in the guinea pig. In cutia, the number of Sertoli cells remained almost constant comparing the groups and no statistical difference was observed. Progressive Sertoli cells deterioration or reduced in number may result in reduced sperm production (Johnson et al. 1987), unfortunately, we did not quantify directly the sperm production, but only the precursor cells.

The alterations in spermatogenesis, following the photoperiod, was investigated by Godoy Pieri et al. (2014). They observed that Sertoli cells of viscachas, captured in summer, had reduced capacity for supporting the developing round spermatids. 
This seasonal rodent produced less sperm during the spring than the summer. Our study did not take into account the photoperiod to estimate the cell numbers and the testicular morphological structure but is suggestive that in the cutia and in the guinea pig, as Hystricomorpha rodents like viscacha, the spermatogenesis also follow it.

The Leydig cells increased approximately $150 \%$ in pubertal guinea pigs and around $19 \%$ in cutias and decreased $4 \%$ in cutia, but increased $65 \%$ in the guinea pig. Neaves et al. (1984) observed a reduction of $44 \%$ comparing the older men to the younger, however, Petersen and Pakkenberg (2000) observed no difference between young and old groups.

In conclusion, germinative cells increased during the pubertal phase in both rodents, as expected. Particular emphasis should be driven to the high proliferation of spermatid cells in pubertal phase and to the proliferation of spermatogonia in adult phase. The Sertoli cells number increased in pubertal guinea pigs and cutias, but the number reduced in adult animals. The Leydig cells doubled in pubertal guinea pigs and remained proliferating in adult phase. In cutias, the Leydig cells proliferating in puberty and slightly reduced in adults. The design-based stereological method has proven to be unbiased and reliable to be applied in reproduction studies.

\section{ACKNOWLEDGMENTS}

We thank Coordenação de Aperfeiçoamento de Pessoal de Nível Superior (CAPES) for LSS scholarship.

\section{REFERENCES}

ARROYO MAM, OLIVEIRA MF, SANTOS PRS AND ASSIS NETO AC. 2014. Ultrastructure of the epididymis and vas deferens of agoutis at different stages of sexual development. Anim Reprod Sci 149: 273-280.

BELLVÉ AR, CAVICCHIA JC, MILLETTE CF, O'BRIEN DA, BHATNAGAR YM AND DYM M. 1977.
Spermatogenic cells of the prepuberal mouse. Isolation and morphological characterization. J Cell Biol 74(1): 6885 .

CARDOSO DL. 2009. Puberdade em caititus (Tayassu tajacu): estudo da espermatogênese em diferentes faixas etárias. Dissertação de Mestrado em Ciência Animal, Universidade Federal do Pará, 73 p. (Unpublished).

CASTELO TS, SILVA AM, BEZERRA LG, COSTA CY, LAGO AE, BEZERRA JA, CAMPOS LB, PRAXEDES EC AND SILVA AR. 2015. Comparison among different cryoprotectants for cryopreservation of epididymal sperm from agouti (Dasyprocta leporina). Cryobiology 71(3): 442-447.

DE MELO FC, DE SOUSA TP, COSTA KL, DA MATTA SL, MELO RF AND SANTA RITA RM. 2013. Descriptive morphometry and stereology of the tubular compartment in the wild rodent Hylaeamys megacephalus (Rodentia: Cricetidae) from Central Brazil. Anim Reprod Sci 138(12): $110-117$.

FRANÇA LR AND RUSSELL LD. 1998. The testis of domestic animals. In: Martinez-Garcia $\mathrm{F}$ and Regadera $\mathrm{J}$ (Eds), Male Reproduction: A Multidisciplinary Overview, Madrid, Churchill Livingston, Madrid, Spain, p. 197-219.

GODOY PIERI NC, DA SILVA SANTOS PR, SANTOS ROBALLO KC, FLAMINI MA, BARBEITO CG, AMBROSIO CE, MIGLINO MA AND DOS SANTOS MARTINS D. 2014. Seasonal variations cause morphological changes and altered spermatogenesis in the testes of viscacha (Lagostomus maximus). Anim Reprod Sci 149(3-4): 316-324.

GUNDERSEN HJ, JENSEN EB, KIÊU K AND NIELSEN J. 1999. The Efficiency of Systematic Sampling in Stereology--Reconsidered. J Microsc 193: 199-211.

GUNDERSEN HJG. 1986. Stereology of arbitrary particles. A review of unbiased number and size estimators and the presentation of some new ones, in memory of William $\mathrm{R}$ Thompson. J Microsc 143: 3-45.

GUNDERSEN HJG. 2002. The smooth fractionator. J Microsc 207: 191-210.

JOHNSON L, NGUYEN HB, PETTY CS AND NEAVES WB. 1987. Quantification of human spermatogenesis: germ cell degeneration during spermatocytogenesis and meiosis in testes from younger and older adult men. Biol Reprod 37(3): 739-747.

MACKENZIE RB. 1972. Public health importance of rodents in South America. Bull World Health Organ 47(2): 161169.

MORAIS AC, BALARINI MK, LOPES EO, MENEZES TP, QUINTELA FM, MORAIS DB, GOMES M DE L AND MATTA SL. 2014. The tubular compartment and the spermatogenic dynamics of the wild rodent Oxymycterus nasutus (Rodentia: Cricetidae). Anim Reprod Sci 149(34): $249-258$. 
MORI H AND CHRISTENSEN AK. 1980. Morphometric analysis of Leydig cells in the normal rat testis. J Cell Biol 84 (2): 340-345.

NEAVES CRJ, JOHNSON J, PORTER JC, PARKER CRJ AND PETTY GJ. 1984. Leydig number, daily sperm production, and serum gonadotropin level in ageing and men. J Clin Endocrinol Metab 59(4): 1-12.

NUNES AKR, GOUVEIA BB AND MATOS MH. 2013. Análise morfológica e funcional do processo espermatogênico em cobaios (Cavia porcellus) da prépuberdade até a pós-puberdade. Pesq Vet Bras 33: 1-7.

OKWUN OE, IGBOELI G, FORD JJ, LUNSTRA DD AND JOHNSON L. 1996. Number and function of Sertoli cells, number yeld of spermatogonia and daly sperm production in three breeds of boar. J Reprod fertil 107: 137-149.

PADILLA-CARLIN DJ, MCMURRAY DN AND HICKEY AJ. 2008. The guinea pig as a model of infectious diseases. Comp Med 58(4): 324-340.
PETERSEN P AND PAKKENBERG B. 2000. Stereological quantitation of Leydig and Sertoli Cells in the testis from young and old men. Image Anal Stereol 19: 215-218.

RODRÍGUEZ RE AND WETTSTEIN RM. 2004. Quantitative study on guinea pig spermatogenesis shows a relative high percentage of early meiotic prophase stages. Anat Rec 278: 493-504.

SHORT RV. 1997. The testis: the witness of the mating system, the site of mutation and the engine of desire. Acta Pediatr Supp 1422: 3-7.

ZHENGWEL Y, ROBERT I, MCLACHLAN WJ, BREMNER TAND WREFORD NG. 1997. Quantitative (Stereological) Study of Normal Spermatogenesis in the Adult Monkey (Macaca fascicularis). J Androl 18(6): 681-687.

WELKOS S, BOZUE J, TWENHAFEL N AND COTE C. 2015. Animal models for the pathogenesis treatment and prevention of infection by bacillus anthracis. Microbiol Spectr 3(1): TBS 0001-2012. 